\section{ODBORNÉ ZDRAVOTNICKÉ E-KNIHY, MOŽNOSTI JE- JICH VYUŽITÍ V KNIHOVNÁCH A STATISTIKY JEJICH VYUŽITÍ}

\section{Lenka Maixnerová, Eva Valdmanová}

\begin{abstract}
Abstrakt
V nabídce elektronických informačních zdrojů (EIZ) knihoven jsou odborné e-knihy již řadu let, ale teprve v posledních letech se významně rozšírily i v ČR. Kromě zahraničních e-knih jsou nyní k dispozici i české e-knihy, které vydávají zejména univerzitní nakladatelství a nakladatelství Grada. E-knihy mohou být do knihoven pořizovány pouze tehdy, pokud jsou ošetřeny tzv. knihovní licencí (jež umožňuje jejich využívání v knihovně), což stále řada nakladatelství neumožňuje. V roce 2019 se prostřednictvím CzechElibu podařilo sjednotit a schválit metody vykazování statistik využívání EIZ, a to včetně e-knih. Pro e-knihy byly schváleny metodiky Counter R5.

NLK nabízí e-knihy na 4 platformách: BookPort, Thieme, EbscoHost a SpringerLink. Př́stup k e-knihám je stále malým segmentem celkového množství nabízených informačních služeb NLK (okolo 900 e-knih), ale z hlediska využívání do budoucna je určitě významnou službou.
\end{abstract}

\section{Klíčová slova}

informační služby, knihovnické služby, lékařské knihovny, zdravotnické e-knihy, e-knihy, statistiky, využití služeb

\section{Úvod}

Elektronické informační zdroje (EIZ) se v nabídce informačních zdrojů knihoven objevují již více než 20 let, ale teprve v posledních letech začínají být ve vyšší míre nabízeny a tím i využívány elektronické knihy. Myšlenka elektronických knih se objevila již v roce 1971, kdy Michael S. Hart založil Projekt Gutenberg. Díky tomuto projektu vznikla digitální knihovna, jejímž obsahem jsou zejména autorskoprávně volná díla. V ČR se však e-knihy většího rozšíření dočkaly až v roce 2010 , kdy se české e-knihy ve větší míre objevily v nabídce e-shopů.[1]

\section{E-knihy v knihovnách}

Půjčování knih v knihovnách je ošetřeno § 37 autorského zákona Knihovní licence. Knihovní licence se však týká pouze užití klasických knih (tj. knih na hmotném nosiči, jako je tištěná kniha, kniha na CD apod.)

Významným rozdílem mezi e-knihami a tištěnými knihami jsou autorská práva. U tištěných knih dochází jejich prodejem k tzv. vyčerpání autorských práv k rozmnoženině díla. Kniha tak může být dále prodána, půjčena, nemůže být pronajmuta či zpřístupněna veřejnosti. U prodeje e-knih nedochází k převodu vlastnického práva $\mathrm{k}$ hmotné rozmnoženině, nemůže tak dojít k vyčerpání autorského práva. Koupí e-knihy získá většinou uživatel pouze právo si ji přečíst, nemưže ji dále prodat, pưjčit nebo darovat.[2]

Z hlediska autorského zákona je použití děl bez hmotného nosiče chápáno jako tzv. sdělování díla veřejnosti. Půjčování e-knih v knihovnách musí být tedy ošetřeno tzv. knihovní licencí uzavřenou mezi knihovnou a nakladatelem, která umožní jejich využívání. Knihovny tak většinou nemají možnost koupit e-knihu v internetovém eshopu, aniž by měly $k$ dispozici svolení kjejímu využití v knihovně. E-knihy s knihovní licencí se tak cenově významně liší od cen e-knih, běžně dostupných v eshopech na internetu. $V$ řadě př́padů není možné ani e-knihu do knihovny zakoupit, protože to nakladatel, knihkupec či distributor nedovoluje.
Při pořizování e-knih do knihovny je nutné vždy zvažovat licenční podmínky jejich užití a to, jakým způsobem budou e-knihy uživatelům knihovny $k$ dispozici. Licenční podmínky mohou např. zahrnovat, kolik uživatelů zároveň může e-knihu využívat, zda pouze 1, více uživatelů nebo neomezený počet uživatelů. Licenční ujednání většinou zahrnují i informaci, zda je e-knihu možné využívat pouze na místě samém, nebo zda je umožněn vzdálený přístup pro registrované uživatele knihovny. Pro zpřístupnění e-knih je také určitě důležité mít k dispozici platformu, která umožní jejich půjčování, proto je vhodné kupovat e-knihy u distributorů/nakladatelů, kteří takovou platformu zajištují, a to včetně dodávání statistik jejich využití.

Odborné e-knihy je možné nakupovat jednotlivě nebo formou kolekcí e-knih nebo jako součást multimediálních databází. Nákupy mohou být uskutečňovány formou trvalého nákupu nebo formou předplatného (většinou na 1 rok). U předplatného kolekcí e-knih je většinou nutné počítat s tím, že během trvání předplatného může dojít ke změně obsahu kolekce, některé tituly zmizí, jiné naopak přibudou. U náhle nedostupných e-knih většinou dojde k vypršení nasmlouvané doby jejich zpřístupnění v kolekci mezi distributorem a nakladatelem nebo samotným autorem.

U trvalých nákupů e-knih může být problémem zaniknutí nebo sloučení provozovatele platformy, na které jsou e-knihy využívány.

Významným počinem v nabídce českých odborných e-knih bylo spuštění platformy BookPort nakladatelstvím Grada v roce 2017. Nabízí přístup k více než 5200 titulům v českém jazyce různých domácích nakladatelů z oborů beletrie, populárně-naučné nebo odborné literatury.

\section{Statistiky využívání e-knih}

Pro statistické vykazování využití EIZ v České republice byla v roce 2019 navržena Odbornou radou CzechElibu Metodika vyhodnocování statistiky využívanosti EIZ. Doporučením je u EIZ používat standard Counter R5. Mezinárodní projekt Counter (Counting Online Usage of NeTworked Electronic Resource) vytváři standardy pro měření využívání EIZ, aby byly vytvářeny a poskytovány důvěryhodné, konzistentní a kompatibilní statistiky. Standard Counter 5 umožňuje pro e-knihy vytvářet a poskytovat tyto reporty:

- TR-B1 - statistiky stažených položek (bez open access titulů) s možností dvojího nastavení:

- Total_Item-Requests (celkový počet požadovaných položek), mủže to být celkový počet stažených knih/ kapitol/částí, podle toho, zda vydavatel nabízí knihu jako celek, nebo po částech, nebo po kapitolách

- Unique_Title-Request (celkový počet unikátních titulů), představuje celkový počet unikátních knih, které byly nějakým způsobem vyžádány (jako celek, část nebo kapitola)

- TR-B2 - statistiky odmítnutých př́stupů s možností dvojího nastavení:

- No-License - ukazuje počty uživatelů, kteří se snažili dostat k dokumentu, ke kterému nemá instituce prístup

- Limit_Exceeded - ukazuje počty uživatelů, kdy se uživatelé snažili dostat $\mathrm{k}$ dokumentu, který má instituce licencovaný, ale pouze pro omezený počet současně pracujících uživatelů

- TR-B3 - statistiky využití všech e-knih včetně volně přístupných s možností nastavení:

- Requests - plnohodnotné čtení nebo stažení

- Investigations - pouhé prozkoumávání různými způsoby $[3,4]$ 
Doporučením CzechElibu je pro vykazování statistik pro e-knihy používat report TR-B1. E-knihy jsou nabízeny $v$ různých režimech uživání, někdy je nutné stáhnout/zobrazit celou knihu (BookPort) někdy je možné zobrazit pouze kapitolu (Thieme), $v$ některých prípadech jsou možné oba způsoby (Ebsco). Co znamená kapitola/část e-knihy, není jednoznačně stanoveno, u encyklopedií to může být i jedno heslo.[5] Při vzájemném porovnávání statistik je nutné počítat s tím, že zdroje s různou možností stažení/zobrazení se nedají vzájemně porovnávat. Statistiky využití e-knih se obtížně porovnávají i s předchozími lety, protože řada dodavatelů e-knih poskytovala jiné statistiky než mezinárodní standard Counter, a to jak domácí tak zahraniční dodavatelé.

U tištěných knih se sledují výpůjčky, a to jak absenční, tak prezenční, včetně prolongací. Velice obtížně lze tak porovnávat statistiky využívání tištěných a elektronických knih.

\section{E-knihy v NLK}

NLK nabízí v současné době e-knihy na 4 platformách: BookPort, Thieme, EbscoHost a SpringerLink, ale mohou být dostupné i v dalších multimediálních databázích.

Na platformě BookPort NLK využívá kolekci českých e-knih Zdravotnická a lékařská literatura, což je přibližně 750 monografií, príruček a učebnic zejména z nakladatelství Grada, Galén, Karolinum či Portál. V mobilních aplikacích Ize využít aplikaci BookPort, a to jak pro Android, tak i iOS.

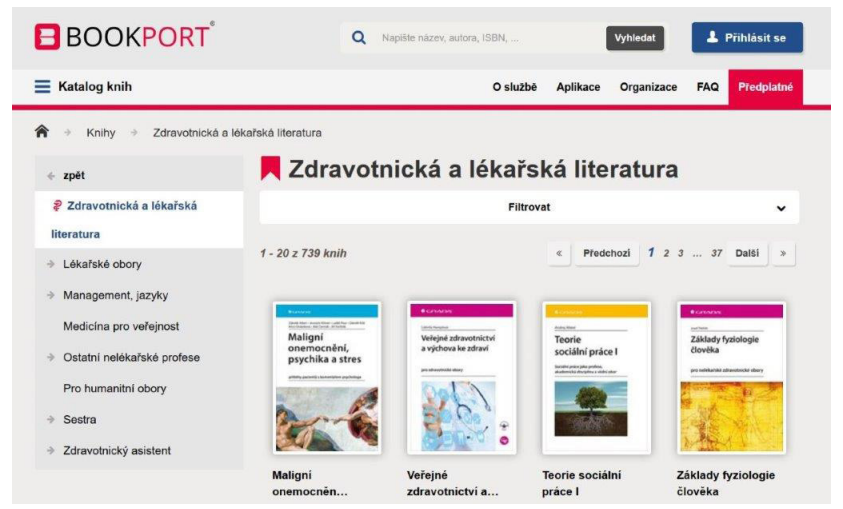

Obrázek 1 - Úvodní obrazovka služby BookPort pro kolekci Zdravotnická a lékařská literatura

Na platformě Thieme využívá NLK kolekci e-knih Thieme MedOne Education, jejímž obsahem je cca 130 anglických titulů učebnic, příruček, monografií, atlasů vydavatelství Thieme včetně plnobarevných ilustrací a videí. Na mobilních zařízeních Ize využít aplikaci MedOne (Android, iOS).

Platformu EbscoHost NLK používá pro individuální nákupy českých i zahraničních e-knih od různých nakladatelů.

Platforma SpringerLink umožňuje NLK přistup ke starší kolekci cca 30 e-knih nakladatelství Kluwer, ke které nejsou k dispozici statistické údaje o využívání.

Výpůjčky tištěných dokumentů se v NLK v posledních letech pohybují okolo 56 tisíc výpůjček za rok. Pro porovnání uvádíme statistiky využívání tištěných knih včetně požadavků na kopie, e-knih, ostatních EIZ a Digitální knihovny NLK. Využití jednotlivých druhů informačních zdrojů je obtížné vzájemně porovnávat, u ElZ uvádíme stažené plné texty, u digitální knihovny zobrazené stránky.

Z grafu využívání informačních zdrojů je zřejmé, že využivání e-knih tvoří okolo 1 \% celkového počtu využívání informačních zdrojů NLK, ale vzhledem k tomu, že se nejedná o velké množství titulů (asi 900 tisíc titulů), není to nevýznamné číslo.
Využití informačních zdrojů v NLK v letech 2018 a 2019

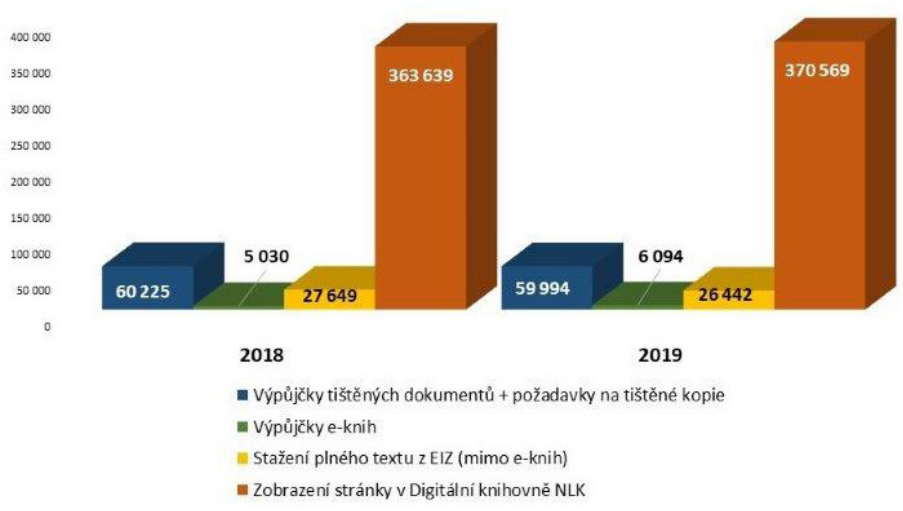

Graf 1 - Využívání informačních zdrojů v NLK v letech 2018 a 2019

Pro vzájemné porovnání mezi informačními zdroji jsme se snažili spočítat průměrný počet výpůjček/stažených textů/zobrazených stránek za rok 2019 k celkovému počtu dokumentů/ plných textů/stránek. U EIZ je velice obtížné spočítat celkové množství dostupných plných textů, celkově je v NLK v roce 2020 dostupných okolo 596 milionů plných textů, číslo však bude ve skutečnosti mnohem vyšší, protože neznáme údaje z elektronických archivů, které má NLK také k dispozici. Jako plný text jsou v multimediálních databázích označeny i novinové články, zprávy atp. Pro vzájemné porovnání jsme u ElZ započítali pouze plné texty z databáze OVID, Medline Complete, Cinahl with Full Text a z databáze Proquest pouze Scholarly Journals.

Tabulka 1 - Celkový stav fondu NLK podle druhu informačního zdroje a statistiky využití za rok 2019

\begin{tabular}{|c|c|c|c|}
\hline & $\begin{array}{c}\text { Celkový } \\
\text { počet }\end{array}$ & $\begin{array}{c}\text { Využití } \\
\mathbf{2 0 1 9}\end{array}$ & $\begin{array}{c}\text { "Využíí } \\
\text { v procentech" }\end{array}$ \\
\hline $\begin{array}{c}\text { "Knižní fond NLK } \\
\text { počet exemplářŭ" }\end{array}$ & 395127 & 59994 & $0,15 \%$ \\
\hline $\begin{array}{c}\text { "E-knihy } \\
\text { počet exemplářu" }\end{array}$ & 873 & 6094 & $7 \%$ \\
\hline $\begin{array}{c}\text { "ElZ (bez e-knih) } \\
\text { počet plných } \\
\text { textů" }\end{array}$ & 24505143 & 26442 & $0,10 \%$ \\
\hline $\begin{array}{c}\text { "Digitální } \\
\text { knihovna } \\
\text { počet stránek" }\end{array}$ & 1705415 & 370569 & $0,20 \%$ \\
\hline
\end{tabular}

Z tabulky a grafu je zřejmé, že přestože e-knihy nejsou v celkovém počtu významnou částí fondu NLK, jejich statistiky využití (průměrná výpůjčka je 7 výpůjček na 1 e-knihu) dokládají, že v nabídce informačních služeb NLK jsou žádoucí. U statistik využívání e-knih je nutné zohledňovat, zda jsou e-knihy nabízené jako celek nebo po částech.

Dále nás zajímalo, které e-knihy a které tištěné knihy jsou nejvíce využívané. Pro obě kategorie jsme vybrali první tři nejvyužívanější tituly. U prvních třech nejvyužívanějších e-knih máme ve fondu NLK i tištěné exempláře, u třech nejvyužívanějších tištěných knih je u dvou k dispozici i e-kniha. V tabulce uvádíme počet tištěných exemplářu ve fondu NLK, kolik z nich je prezenčních $(P)$ a kolik absenčních $(A)$, zda existuje e-kniha a s jakou licencí, kolik bylo výpůjček tištěných a kolik elektronických. 


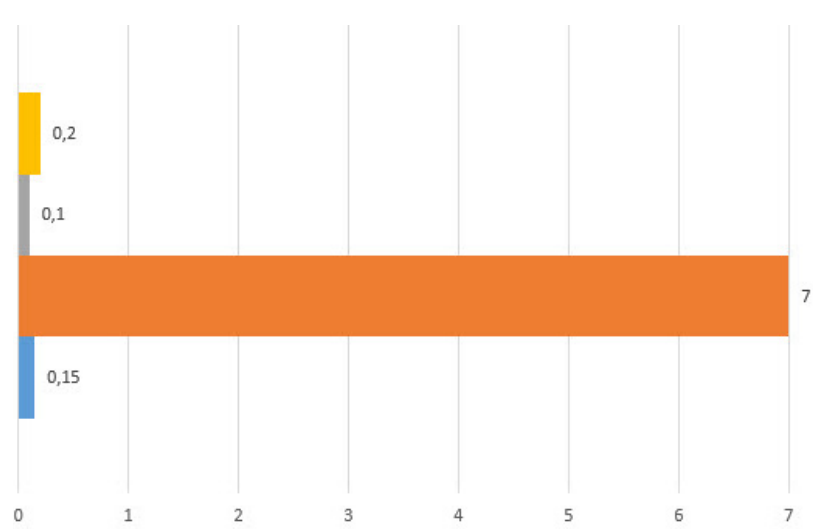

Graf 2 - Průměrný počet výpůjček, stažených plných textů či zobrazených stránek u 1 dokumentu, e-knihy, plného textu a zobrazované stránky za rok 2019 vzhledem k celkovému počtu dokumentů, e-knih, plných textů a zobrazovaných stránek.

Tabulka 2 - Porovnání 3 nejvyužívanějších e-knih a nejpůjčovanějších tištěných knih v NLK

\begin{tabular}{|c|c|c|c|c|c|}
\hline & Název knihy & $\begin{array}{c}\text { Počet } \\
\text { tištěných } \\
\text { exemplářů }\end{array}$ & $\begin{array}{l}\text { "Licence } \\
\text { e-knihy" }\end{array}$ & $\begin{array}{l}\text { Počet } \\
\text { výpůjček } \\
\text { tištěných } \\
\text { knih }\end{array}$ & $\begin{array}{l}\text { Počet } \\
\text { výpưjček } \\
\text { e-knih }\end{array}$ \\
\hline \multirow{3}{*}{$\begin{array}{c}\text { Nejvyužívanější } \\
\text { e-knihy za rok } \\
2019\end{array}$} & Farmakologie & "3 (2A, 1P)" & neomezená & 23 & 133 \\
\hline & $\begin{array}{l}\text { Intenzivní } \\
\text { medicína }\end{array}$ & "3 (2A, 1P)" & neomezená & 20 & 116 \\
\hline & Anatomie 1 & "4 (3A, 1P)" & neomezená & 38 & 112 \\
\hline \multirow{3}{*}{$\begin{array}{l}\text { Nejvyužívanější } \\
\text { tištěné knihy za } \\
\text { rok } 2019\end{array}$} & $\begin{array}{c}\text { Rehabilitace } \\
\text { v klinické praxi }\end{array}$ & "6 (5A, 1P)" & 0 & 45 & 0 \\
\hline & $\begin{array}{l}\text { Fyzikální } \\
\text { terapie I. a II. }\end{array}$ & $\begin{array}{l}\text { "9 (I. 3A, 1P, } \\
\text { II. 4A,1P)" }\end{array}$ & neomezená & 25 & 32 \\
\hline & $\begin{array}{l}\text { Ošetřovatelství } \\
\text { v chirurgii II }\end{array}$ & "4 (3A, 1P)" & neomezená & 24 & 19 \\
\hline
\end{tabular}

Z tabulky nejvyužívanějších titulů je vidět, že e-knihu může využít mnohem více uživatelů, než tištěnou verzi, kde je využití limitováno počtem exemplářù $v$ knihovně a to, zda je možnost absenční výpůjčky (ve většině prípadů je 1 exemplář pouze prezenční). Podle Akvizičního plánu NLK se pořizují většinou od odborného titulu 3 tištěné exempláře, z nichž 2 jsou absenční a 1 prezenční. Výpůjční lhůta u tištěných dokumentů je 31 dní, a pokud není dokument rezervován jiným uživatelem, může být výpůjční lhůta $3 x$ prodloužena. U e-knih z platformy BookPort je pouze omezení na množství zároveň stažených e-knih (off-line čtení) pro jednoho uživatele na 5 titulů, u online čtení žádné omezení není.

\section{Závěr}

Ze statistik využití e-knih v NLK je zřejmé, že je o tento druh informačních zdrojů zájem. Neznamená to, že by uživatelé upřednostňovali čtení e-knih před tištěnými knihami, ale mohou být pro ně dostupnější, a to 24 hodin denně, včetně možnosti vzdáleného př́stupu. Schválením použití ve vykazování statistik EIZ pro ČR mezinárodního standardu Counter byli dodavatelé EIZ donuceni začít tyto statistiky poskytovat. Přestože není vždy možné porovnávat statistiky využití různých EIZ od různých dodavatelů (zejména u e-knih), je zajištěna možnost vzájemného porovnání u stejných ElZ u různých institucí.

Při vzájemném porovnání výpůjček u shodných tištěných a elektronických titulů vyplynulo, že nedochází ke snížení vyu- žívání tištěných verzí, přestože je dostupná i elektronická verze, a že elektronické verze umožňují vyšší využití.

Vzhledem k tomu, že e-knihy jsou v nabídce služeb NLK až v posledních letech a s jednotnou statistikou teprve jeden rok, je určitě žádoucí sledovat trendy ve využívání v této oblasti. Do budoucna by určitě bylo vhodné zjistit uživatelské preference čtenářu NLK ohledně nabízených e-knih, zda vyhovují formáty, registrace, aplikace, proč je uživatelé chtějí nebo naopak nechtějí využívat. 


\section{Literatura}

[1.] VOJÁČKOVÁ, Martina. Zájem veřejnosti o nabídku e-knih v knihovnách a jejich využívání. Brno, 2018. [cit. 2020-02-14]. Dostupné z: https://is.muni.cz/th/svz69/bakalarka-full_text.pdf. Masarykova univerzita, Filozofická fakulta. PhDr. Martin Krčál, DiS.

[2.] Hájková, Zuzana. E-knihy a knihovny [online]. [cit. 2020-02-14]. Dostupné z: https://ipk.nkp.cz/docs/rkk/hajkova-zuzana-e-knihy-a-knihovny/at download/file

[3.] Metodika vyhodnocování statistiky využívanosti EIZ. In: CzechELib [online]. 2019, srpen 2019 [cit. 2020-02-17]. Dostupné z: https://www. czechelib.cz/default/files/download/id/279/metodika-vyhodnocovani-statistiky-vyuzivanosti-eiz.pdf

[4.] The COUNTER Code of Practice for Release 5.Counter [online]. [cit. 2020-02-17]. Dostupné z: https://www.projectcounter.org/code-of-practice-five-sections/abstract/

[5.] CONYERS, Angela, Jo LAMBERT, Laura WONG, Hilary JONES, Marianne BAMKIN a Pete DALTON. E-book usage: counting the challenges and opportunities. Insights the UKSG journal [online]. 2017, 30(2), 26-33 [cit. 2020-02-17]. DOI: 10.1629/uksg.370. ISSN 2048-7754. Dostupné z: http://insights.uksg.org/articles/10.1629/uksg.370/

\section{Kontakt}

Mgr. Lenka Maixnerová e-mail:maixnerova@nlk.cz

\section{PhDr. Eva Valdmanová}

Národní lékařská knihovna Sokolská 54

12132 Praha 2 